\title{
Student Adoption \& Development of Digital Learning Media: Action Research and Recommended Practices
}

\author{
Sharon W. Tabor and Robert P. Minch \\ Boise State University, Boise, Idaho, USA
}

stabor@boisestate.edu rminch@boisestate.edu

Executive Summary

Digital technologies offer many opportunities for creating engaging course content. In this study we captured student perceptions and adoption choices related to creating and using digital media as learning tools. Podcasts, video and other media were integrated in a variety of contexts and tasks in two undergraduate information technology (IT) courses in a college of business.

During the fall semesters of 2009 and 2010, faculty members teaching a junior-level IT and networking concepts course and a senior-level information security course, produced video-captured lectures, recorded fine-grained conceptual tutorials and podcasts, developed software simulations, and provided media for ad-hoc learning assistance. Students produced video for several class assignments. They also had the option of replacing a typical written semester report with a video project. Student satisfaction with the various forms of digital learning media, perceptions of learning, and intention to adopt for future courses were measured in a series of surveys and compared to self-reported learning styles. Of particular interest was how students would perform and respond to the higher order learning activity of creating digital output. Outcomes were generally positive, and in some cases, students reported that access to digital media positively changed the way they prepared for class and studied for exams. While students reported that developing digital media was preferable to traditional projects and felt they learned more about their topics during the process of developing a video or simulation, they noted the time commitment was high. They are not yet ready to see digital media used exclusively for content delivery and expressed a preference for a mix of media and traditional classroom lectures. The paper concludes with suggestions for introducing digital learning media into an IT curriculum.

Keywords: IT education, digital media, podcasting, video production, Bloom's Taxonomy, constructivist learning theory, learning styles.

\section{Introduction}

Material published as part of this publication, either on-line or in print, is copyrighted by the Informing Science Institute. Permission to make digital or paper copy of part or all of these works for personal or classroom use is granted without fee provided that the copies are not made or distributed for profit or commercial advantage AND that copies 1) bear this notice in full and 2) give the full citation on the first page. It is permissible to abstract these works so long as credit is given. To copy in all other cases or to republish or to post on a server or to redistribute to lists requires specific permission and payment of a fee. Contact Publisher@InformingScience.org to request redistribution permission.
Teaching in the IT discipline offers many opportunities to incorporate technology into the classroom. While we are challenging our students to learn about technology, we also want to help them build useful business skills and an interest in life-long learning. A major challenge in IT education is to develop learning experiences that contribute toward skills development while expanding the foundations of known pedagogi- 
cal techniques. In this project, we were interested in exploring the use of digital learning technologies to enhance content in two courses in an IT major. The fundamental purpose of this article is to share what we have learned.

Essentially we wanted to see if we could engage students in more active learning by exposing them to digital audio and video technologies and having them create their own videos. In doing so we are interested in several related issues including whether they will choose to adopt these technologies when they are voluntary, whether they perceive them to contribute to positive learning experiences, and how they affect certain activities such as studying. We are aiming at supporting higher-order thinking skills, and address not only how we support these, but also whether learning styles affect expectations and learning experiences while exposed to digital media.

The study draws upon several areas of theory, primarily the mature constructivist learning theory which supports active learning, and learning style theory, the study of learning preferences based upon a student's perceived learning style. The following section gives a brief overview of recent work in these research areas and how it applies to the current study.

\section{Learning Theory Supporting IT Education}

Educators have long embraced the importance of incorporating higher level thinking skills into their courses (Anderson \& Sosniak, 1994; Buckley, 2003; Forehand, 2010). A well cited and widely adopted model is Bloom's Taxonomy (Bloom et al., 1956). Reflecting global interest, the model has been translated into 22 languages to date. The model on the left side of Figure 1 is the legacy version, often used for developing classroom activities and assessment items. An updated model developed by Bloom's peers is shown on the right in Figure 1 (Anderson \& Krathwohl, 2001). Creating replaces Evaluation as the highest skill in the cognitive domain; each level also describes ongoing action rather than a state or process (Anderson \& Krathwohl, 2001). This update is compelling and may better identify the type of thinking students should employ to be successful in information technology courses and the work place.
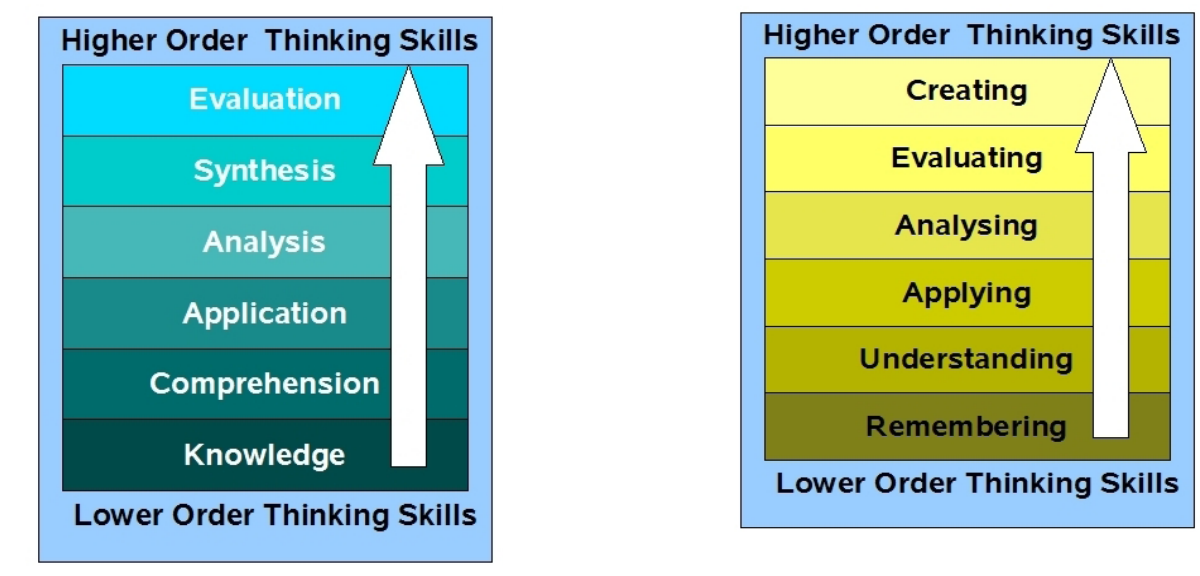

Figure 1. Revised Bloom's Taxonomy (Anderson \& Krathwohl, 2001 in Churches, 2009, used with permission.)

While the revision of Bloom's Taxonomy is an important improvement, the new model still focuses on the cognitive aspect of learning yet leaves open the question of how to deploy active learning in the classroom and, of particular interest to IT faculty, how to use technology to achieve these higher order thinking skills. In Churches' work (2009), collaboration facilitated by digital media is an increasingly important aspect of learning for today's students. As shown in 
Figure 2, Churches further expanded the revised taxonomy by translating each skill level into actionable tasks. He then tied each learning process to contemporary Web 2.0-based learning technologies which can be used in information technology education. The highest order thinking skill of creating is further expanded into designing, constructing, planning, and producing, all examples of active learning in IT education that produces usable workplace skills.

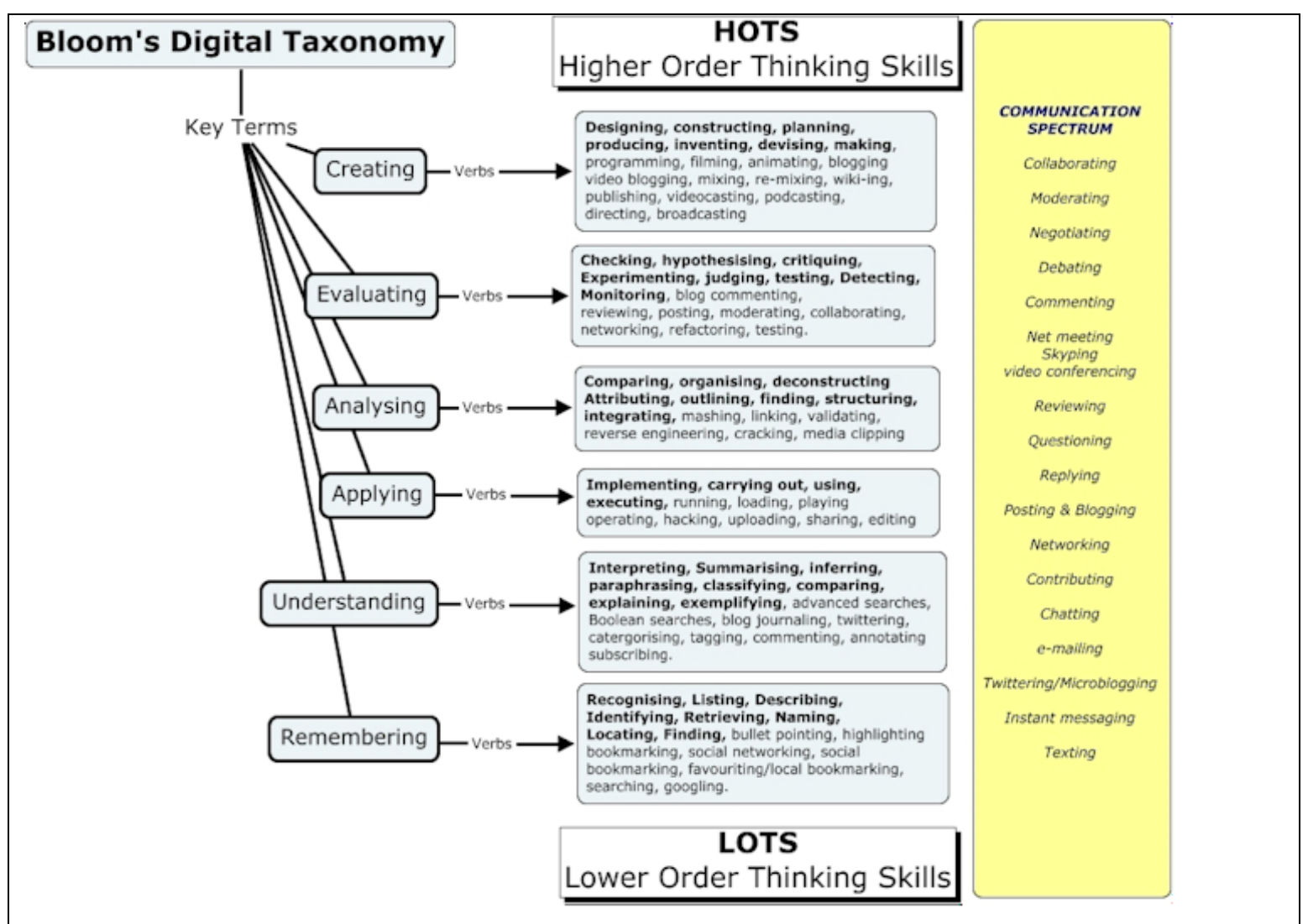

Figure 2. Updated Bloom's Mapped to Digital Learning Domains (Churches, 2009, used with permission.)

While Churches' work defines the path to digital learning, Bower, Hedberg, and Kuswara (2010) remind us that an essential step in using the taxonomy with technology is understanding that "technology is simply the mediator for collaboration and representation, and that it is the type of task and thinking processes in which students engage that determines the quality of learning" (p. 181). Their work suggests the need to better define the pedagogy for how technology achieves desired outcomes. Mishra and Koehler (2006) also emphasized this approach and the importance of finding the intersection of technological, pedagogical, and content knowledge. They support choosing pedagogies with interactive approaches in the learning design, the use of Web 2.0 tools with a social emphasis, micro-content orientation, and open access, all applied within the content of the specific discipline. Manochehri and Sharif (2010) measured attitudes toward learning with various classroom technologies. They found that technology increased students' capacity for selfdirected learning, and that overall acceptance of technology was related to student perception of relevance of the learning experience.

Bower et al. (2010) summarized learning methods that support course pedagogies and address the desired level of learning. Their recommended categories include: 
Transmissive - content delivered to learners (lecture)

Dialogic - exchange between participants, with activity and feedback (discussion)

Constructionist - learning by developing output (blogs, journals, targeted activity)

Co-constructionist - team-based, goal related tasks leading to some output

When planning for learning in a new knowledge domain, all four levels might be useful as part of a learning cycle. For example, transmissive methods may be used at the beginning of the learning cycle introducing new concepts, building up to constructionist methods as learners understand foundation topics. The philosophy of constructionist pedagogy, originally described by Papert (1986), assumes that students learn most effectively when they are creating a meaningful product, such as our goal of student-created digital output. Team based learning fits within the $c o-$ constructionist category, where groups of learners benefit from peer learning along with the end goal of creating a defined output (Bower et al., 2010).

Papert's conceptual model is more about the art of learning, or learning to learn (Ackermann, n.d.). Each student constructs their own meaning and understanding of what they learn, and "this happens especially felicitously in a context where the learner is consciously engaged in constructing a public entity, whether it's a sand castle on the beach or a theory of the universe" (Papert, 1991, p.1 as cited in Ackermann, n.d.). In other words, Papert recognized the individual learner's interpretation and understanding of the content as well as the style with which they processed new knowledge. In his later work, he focused on digital media and computer-based technology as well as the type of initiative the learner displays (Ackermann, n.d.). While his theories are different, yet compatible, with his mentor, Piaget, constructivism today relates directly to applied or hands-on learning that leads to the delivery of student output.

Both constructionist theory and Bloom's higher order learning skills are demonstrated in this study through student development of digital learning media in teams. During the process of developing podcasts, simulations, or videos, students had to research their chosen topics, plan their delivery medium and outcomes, learn and use a variety of technical tools with minimal training, and also understand the material well enough to explain it to their peers. This technique further supports our college goal of emphasizing problem-based learning, by moving thought and analysis into action.

\section{Learning Style Instruments}

Building upon the foundation work of Papert (1986) and others (Bower et al., 2010), studies on learning styles and preferences led to the development of several important instruments. These self reporting instruments attempt to identify characteristics or traits that impact learning, with the desired outcome that a better understanding of student learning will help us design courses that better meet learner needs. Table 1 shows four of the best known learning styles instruments along with key characteristics measured. 
Table 1. Summary of Major Instruments Measuring Learning Styles

\begin{tabular}{|l|l|}
\hline \multicolumn{1}{|c|}{ Instrument, Developer, Timeframe } & \multicolumn{1}{c|}{ Key Characteristics Measured } \\
\hline $\begin{array}{l}\text { Kolb's Learning Style Inventory - LSI (1976, } \\
\text { 1981, 1984, 1993, 1999) - Theory of Experi- } \\
\text { ential Learning }\end{array}$ & $\begin{array}{l}\text { Concrete experience (CE) - feeling, reflective obser- } \\
\text { vation (RO) - watching, abstract conceptualization } \\
\text { (AC) - thinking, active experimentation (AE) - do- } \\
\text { ing (4 types) }\end{array}$ \\
\hline $\begin{array}{l}\text { Myers-Briggs Type Indicator (1921, 1971) - } \\
\text { based on Jung's personality types - MBTI } \\
\text { (1921/1951) }\end{array}$ & $\begin{array}{l}\text { Extrovert/introvert (EI), thinking/feeling (TF), judg- } \\
\text { ing/perceiving (JP) - (16 learning type combina- } \\
\text { tions) }\end{array}$ \\
\hline $\begin{array}{l}\text { Herrmann Brain Dominance Instrument - } \\
\text { HBDI (1990) }\end{array}$ & $\begin{array}{l}\text { Left brain, cerebral; left brain, limbic; right brain, } \\
\text { limbic; right brain, cerebral (4 types) }\end{array}$ \\
\hline $\begin{array}{l}\text { Felder and Soloman's Index of Learning Styles } \\
\text { - ILS (1999, 2005) }\end{array}$ & $\begin{array}{l}\text { Sensing/intuitive; visual/verbal; active/reflective; } \\
\text { sequential/global (4 types) }\end{array}$ \\
\hline
\end{tabular}

Kolb's Learning Style Inventory (LSI) is one of the most widely used instruments, followed closely by the Myers-Briggs Type Indicator (MBTI), based on Jung's work with personality types. The Herrman Brain Dominance instrument, while not a measure of learning styles on the scope of the others, can explain success with various subjects. Felder and Soloman's Index of Learning Styles (ILS) is a newer entrant, based upon a model developed for engineering students by Felder and Silverman in 1988 and later expanded to other disciplines. The ILS's dimensions of active/reflective are comparable to the same dimension on the Kolb's LSI, and the active/reflective dimension is related to the Myers-Briggs extravert/introvert. The sequential/global dimension is based upon the Hermann Brain Dominance view of left-brain/right-brain (Felder \& Spurlin, 2005; Rosati \& Felder, 1995).

While commonly used in a wide of range of research studies, all of these instruments are selfreporting devices, and each has noted limitations. The LSI has been challenged for its construct validity although showing strong internal reliability, while the ILS as the newest entrant is still being examined and has both supporters and detractors (Platsidou \& Metallidou, 2009). Additionally, learner preference on the four scales of the ILS fits within a range and may vary over time, subject, or learning environment (Platsidou \& Metallidou, 2009). Research data supports construct validity in the ILS, along with convergent and discriminant validity across different subjects (Felder \& Brent, 2005; Felder \& Spurlin, 2005 in Platsidou \& Metallidou, 2009).

Key to the successful use of learning styles is the assumption that learning style is a "stable and predictable characteristic" (Salter, Evan, \& Forney, 2006, p.173). Slater et al. performed a longitudinal study to test stability in learning styles as measured by the MBTI and Kolb's LSI. In their study, thirteen cohorts of graduate students from 1987 through 2001, including 222 total subjects, completed a single version of both instruments three times over the course of their studies. The MBTI results showed reasonably strong consistency over time, while more variation was observed with the LSI. According to Salter et al. (2006), one limitation of the study was that it only observed change and not the reason for the change. An additional line of research postulated that cognitive complexity is likely to increase over time, as students mature and gradually encounter more complicated content and scenarios during their education process.

Sardone (2011) examined various learning characteristics (math background, math ability, cumulative GPA, and learning style) and their relationship to learning environment (traditional or constructivist), course satisfaction, and IT fluency (learning to learn about IT) using the Kolb's LSI. In her study, GPA and math ability as measured by SAT scores were more significant indicators of IT fluency than was learning style. However, students with an assimilating learning style 
scored better on the final exam in a traditionally taught environment, with few other notable relationships viewed other than course satisfaction. While IT fluency was not significantly different related to learning environment, Sardone found that instructional methods could increase satisfaction.

Platsidou and Metallidou (2009) studied and compared validity and reliability for the LSI and ISL. In their study, 340 primary school teachers and undergraduate university students from several departments completed the two instruments. Kolb's LSI model again proved to have satisfactory reliability but lower than desired construct validity. No significant differences were found in learning style profiles across four discipline groups. This is contrary to other findings which found the LSI able to discriminate learning styles relative to their discipline (Clump \& Skogsberg, 2003; Jones, Reichard, \& Mokhtari, 2003). The ILS analysis revealed good construct validity but low reliability indices (Platsidou \& Metallidou, 2009).

Clearly there are weaknesses and limitations in each of the currently available learning styles instruments and they should be used with that understanding. They may still be considered a useful communication tool between student and teacher, and may help students understand more about their own learning experiences. Felder and Spurlin (2005) suggest two specific uses of such instruments:

1. Provide guidance to instructors on the diversity of learning styles within their classes $\&$ to help them design instructional methods that appeal to a variety of styles

2. Give individual students insights into their possible learning strengths and weaknesses and to take ownership for their own learning (p. 110-111)

Cegielski, Kazen, and Rainer (2011) note that learning styles are notably absent in information systems development research. They chose the ILS for their research in teaching object oriented development based upon its successful use in several technology related studies. Over their four year study they found student preferred learning styles did not vary over the semester. Their work supports positive performance outcomes when using teaching techniques related to student visual-verbal attributes of learning styles. Ahmed, Campbell, Jaffar, Alkobaisi, and Campbell (2010) used the MBTI to explore success in a software engineering course. While previous research showed good developers to be highly introverted individuals, the Ahmed et al. study showed extroverted students could also demonstrate high performance, although with a wider range of performance variance. While many successful students in their study demonstrated an introverted personality, they found the thinking/judging dimension was more significant for performance outcomes than the introvert/extrovert characteristic.

\section{Research Goals}

As noted in the previous section, there is substantial support for the identification of learning styles and the ability to improve learning outcomes through appropriate modifications to course design. In this study, we began with the specific goals listed below and compared outcomes to student self-reported learning style preference:

1. Enhance student engagement and learning with course concepts and activities by using digital media produced both by students and faculty.

2. Evaluate student perceptions, adoption choices, and satisfaction both with studying and creating digital media as part of the learning process.

3. Determine whether certain learning styles are related to the above perceptions, adoption choices, and satisfaction measures.

4. Develop a set of good practices for future courses and to share with others. 


\section{Methodology}

This study was conducted over two fall semesters in 2009 and 2010. The target population included undergraduate juniors and seniors in an Information Technology Management (ITM) program at an urban university. The ITM program is part of a college of business and includes a mixture of traditional college aged students, returning military personnel, and second degree/career changing students with varying levels of work experience. In the first year of the study, 88 students participated, including 60 students from two sections of a junior level networking course, and 28 students from a senior information security course. In the second year of the study, 86 students participated; 51 students participated in the networking class, where the majority of students were exposed to digital course content and activities for the first time. The majority of the 35 students in information security in year two had previously completed the networking class and, therefore, had some experience in using and developing digital media.

\section{Data Collection}

We collected data from students three times during the semester in which they were involved in the study. During the first week, students in each course section completed the Index of Learning Style Inventory (Felder, 1996) and a pre-course technology experience survey. The ILS was chosen because it is a well validated instrument that measures student preference for specific learning styles in various situations and majors. It incorporates key components of prior instruments, is freely available to researchers, and can be administered either on paper or via the online version (http://www.engr.ncsu.edu/learningstyles/ilsweb.html). The pre-course technology survey, developed by the instructors, has been used over several years to identify student strengths and experiences with technology at the start of a semester. Two additional survey instruments, also developed by the instructors, were used across all sections: a mid-term assessment survey measured to what extent students were using the course materials and for what purposes, and the final media survey requested feedback on student use and preferences for the various learning media available to them. As it was important to compare results across the instruments with each student's learning style, we followed all university polices related to human subjects and confidentiality of data collected (see the Appendix for survey instruments).

\section{Study Overview}

The first year of the experiment was a learning process for both faculty and students. We started with a review of resources and technologies available and selected the courses in which we would be applying these new pedagogical techniques. The two courses selected were: IT and Networking Essentials and Information Security. We identified, selected, and experimented with appropriate production tools, and modified course flow and content to incorporate the new technologies. We then developed plans to include media in the selected courses during the summer of the first year, reviewed and acquired software tools to support the plan, and revised existing course syllabi and activities to include a variety of digital tools and development activities. We also sought out campus resources already acquainted with or using some of the tools we targeted, and took advantage of this expertise both to reduce our own learning curve and to help instruct students on the technologies chosen. These initial plans varied as determined by student experience levels and upon mid-term use and feedback.

\section{Course Redesign and Content Creation}

There were two fundamental elements to this initiative. As described below, the instructors employed a variety of techniques to incorporate digital content into the course design. Additionally, student selected assignments were created that required student production and submission of 
digital artifacts in lieu of traditional written assignments. Additional description of these efforts follows below.

IT and Networking Essentials is a technical course that introduces students to the underlying networking concepts and standards that drive the networking technology they use every day. The course includes a 1-credit lab with hands on activities that reinforce classroom learning. This course emphasized a lecture capture approach. Selected lectures of the course used the Echo360 ${ }^{\mathrm{TM}}$ platform for recordings, in both a regular classroom and dedicated facilities in an Instructional Technology Center. In the classroom and dedicated facilities the classroom capture version of the system recorded the full class sessions. In addition, while the professor was out of town attending a professional conference, the personal capture version was used from a laptop computer in a distance learning approach. The broad objective was to use a variety of venues, modes, and contexts to assess the feasibility and effectiveness of each.

Information Security is a senior-level course that builds upon technology concepts that students have worked with in their program by looking at the need and justification for security in organizations. It uses a problem solving approach to IT security at each level of the OSI model and within all business processes touched by IT.

In year 1 of the study this course was redesigned using an inverted classroom model. The professor developed digital podcasts for each weekly topic and made them available to students on iTunes University for preview before each class meeting. A set of eleven podcasts introduced and clarified weekly topics and reading materials, replacing much of the typical classroom lecture component. Available in both MP3 audio and MP4 movie formats, students had the option of listening and/or viewing the media on various technology platforms. Podcast notes were posted on the course management site for each of the digital recordings. The use of the digital "pre-lecture" material allowed more class time for interactive discussion, hands-on labs, and team activities, while quizzes assessed student preparation and learning.

For both courses, we searched for short videos from a number of sources including aggregators who specialize in the content area of the course (e.g., Google's "Tech Talk" series). Ideal choices included networking videos that covered basic, reusable content. Security oriented webcasts and tutorials that supported topics covered in podcasts or for in-class presentation and discussion were available from both academic-oriented sites, such as Merlot, and industry-oriented webcasts. Examples include CSO.com, Network World, SANS Institute, and presentations from the local chapter of the ISSA (Information Systems Security Association).

We found one challenge with public media is not an absence of material, but an overabundance; all of it needed curation to determine relevance and timeliness to course content. For both courses, we emphasized reuse for future semesters.

\section{Content Created by Students}

Students in the networking course created videos for two assignments. One was a relatively simple homework assignment early in the course, designed to familiarize students with basic tools and techniques of video creation. Before this assignment students attended a hands-on training session in a campus facility supporting student technology needs. The second assignment was the class project, where a 20 -minute video produced by student project groups was an optional substitute for a traditional written report and presentation. A majority of project groups opted for the video format and later completed a survey about their experiences and satisfaction with this form of class project and their resultant learning.

Students in the security course also completed two digital media projects. Prior to the first project, security students also attended a training and demo session conducted by technology support 
staff. For the first project they worked in teams of 1-3 to develop a short, 5-minute video or simulation that explained a technical aspect of security. This activity replaced a writing assignment intended for posting on the course service learning website. The second video project was a slightly longer team effort of 8-10 minutes, submitted along with a short paper of 5-6 pages for their semester project. Some teams explained security flaws in web based applications, while others demonstrated weaknesses in various technologies or how a security control could reduce vulnerabilities.

\section{Findings/Results}

This section contains findings from the learning styles instrument and other surveys. Not all questions have the same total sample size due to absences, non-responses to specific questions, or other data summarization issues.

\section{Demographics}

Groups in the tables below are labeled by course topic (Net=Networking, Sec=Security) and year (1 or 2). Gender within the four sections is shown in Table 2 . These numbers are fairly consistent across all courses in our ITM major. Participants were $76.1 \%$ male and $23.9 \%$ female. Usable data were available for 134 subjects across all sections.

Table 2. Gender Distribution across Sections

\begin{tabular}{|c|c|c|c|}
\hline Course \& Section & Male & Female & Totals \\
\hline Net 1 & 31 & 12 & 43 \\
\hline Sec 1 & 21 & 6 & 27 \\
\hline Net2 & 30 & 7 & 37 \\
\hline Sec2 & 20 & 7 & 27 \\
\hline Totals & 102 & 32 & 134 \\
\hline$\%$ & $76.1 \%$ & $23.9 \%$ & $100 \%$ \\
\hline
\end{tabular}

\section{Learning Style Preferences}

Of the four major learning styles categories, students leaned heavily to the Visual dimension of the Visual/Verbal category, as well as toward the Sensor dimension of the Sensor/Intuitive category. Students were fairly balanced for the Active/Reflective category and leaned slightly toward Sequential in the Sequential/Global category (see Table 3). The visual learning style has been identified as a preference for many IT majors (Reed \& Oughton, 1998; Zualkerman, 2006).

Table 3. Outcomes of ILS Administration (Felder \& Soloman, 1993).

\begin{tabular}{|c|c|c|c|}
\hline Visual/Verbal & Sensor/Intuitive & Active/Reflective & Sequential/Global \\
\hline $116(86.6 \%) / 18$ & $102(76.1 \%) / 32$ & $66(49.2 \%) / 68$ & $74(55.2 \%) / 60$ \\
$(13.4 \%)$ & $(23.9 \%)$ & $(50.7 \%)$ & $(44.8 \%)$ \\
\hline $\begin{array}{c}\text { Visual learners are } \\
\text { drawn to what they } \\
\text { see, while verbal } \\
\text { learners get more } \\
\text { from written or spo- } \\
\text { ken explanations }\end{array}$ & $\begin{array}{c}\text { Sensing learners pre- } \\
\text { fer facts \& solving } \\
\text { problems, while intui- } \\
\text { tive learners prefer to } \\
\text { discover possibilities } \\
\text { \& relationships, \& } \\
\text { lean toward innova- } \\
\text { tion }\end{array}$ & $\begin{array}{c}\text { Active learners retain } \\
\text { a understand best by } \\
\text { ing it to others, \& pre- } \\
\text { fer group work. Re- } \\
\text { flective learners prefer } \\
\text { to think about a prob- } \\
\text { lem \& work it out } \\
\text { alone }\end{array}$ & $\begin{array}{c}\text { Sequential learners } \\
\text { prefer a step by step } \\
\text { approach to gain un- } \\
\text { derstanding, while } \\
\text { global learners absorb } \\
\text { materials in large } \\
\text { chunk to grasp the big } \\
\text { picture of a problem } \\
\text { before considering de- } \\
\text { tails }\end{array}$ \\
\hline
\end{tabular}


The ILS interpretative information suggests a score of 1 to 3 represents a balanced style, a moderate preference at 5 to 7 points, and a strong preference with a score of 9 to 11 . Positive to negative scoring represents the range of preference between the two opposing characteristics (Felder \& Soloman, 1993). For the balance of these tables, we use Felder's scale of 5 or more to categorize a specific preference. As shown in Table 4, the predominant self-reported learning style across all groups was visual for the visual/verbal dimension, with $65 \%$ of participants showing high (-5 to -11) visual learning tendencies.

Table 4. Visual-Verbal Learning Dimension by Group

\begin{tabular}{|c|c|c|c|c|c|c|c|c|c|c|c|c|c|c|c|c|}
\hline & \multicolumn{14}{|c|}{ VISUAL/VERBAL } & \multirow[b]{2}{*}{ Total } \\
\hline & & -11 & -10 & -9 & -7 & -6 & -5 & -3 & -1 & 0 & 1 & 3 & 5 & 7 & 9 & \\
\hline \multirow[t]{4}{*}{ Group } & Net1 & 4 & 0 & 10 & 5 & 0 & 7 & 7 & 4 & 0 & 2 & 2 & 1 & 1 & 0 & 43 \\
\hline & Sec 1 & 7 & 0 & 6 & 2 & 0 & 5 & 4 & 1 & 2 & 0 & 0 & 0 & 0 & 0 & 27 \\
\hline & Net2 & 8 & 1 & 5 & 6 & 1 & 3 & 6 & 1 & 0 & 3 & 0 & 1 & 1 & 1 & 37 \\
\hline & $\operatorname{Sec} 2$ & 5 & 0 & 8 & 2 & 0 & 4 & 2 & 2 & 0 & 0 & 4 & 0 & 0 & 0 & 27 \\
\hline \multicolumn{2}{|l|}{ Total } & 24 & 1 & 29 & 15 & 1 & 19 & 19 & 8 & 2 & 5 & 6 & & 2 & 1 & 134 \\
\hline \multicolumn{2}{|l|}{ Percent } & \multicolumn{6}{|c|}{$66.4 \%$} & & & & & & \multicolumn{3}{|c|}{$.03 \%$} & \\
\hline
\end{tabular}

For comparative purposes, Table 5 shows the range of active/reflective learners across the 4 sections, with $24.6 \%$ of our population showing high (-5 to -11) active learning tendencies.

Table 5. Active-Reflective Learning Dimension by Group

\begin{tabular}{|c|c|c|c|c|c|c|c|c|c|c|c|c|c|c|c|c|c|c|}
\hline & \multicolumn{16}{|c|}{ ACTIVE/REFLECTIVE } & \multirow[b]{2}{*}{ Total } \\
\hline & & -11 & -9 & -7 & -5 & -4 & -3 & -1 & 0 & 1 & 2 & 3 & 4 & 5 & \begin{tabular}{l|l}
7 & 9
\end{tabular} & $9 \quad 10$ & 11 & \\
\hline \multirow[t]{4}{*}{ Group } & Net1 & 1 & 0 & 3 & 8 & 1 & 3 & 2 & 1 & 9 & 0 & 5 & 1 & 4 & 3 & 1 & 1 & 43 \\
\hline & Sec1 & 4 & 0 & 3 & 2 & 0 & 3 & 4 & 2 & 2 & 0 & 3 & 0 & 3 & 0 & 1 & 0 & 27 \\
\hline & Net2 & 0 & 2 & 1 & 1 & 0 & 5 & 5 & 1 & 9 & 1 & 6 & 0 & 5 & 0 & 0 & 0 & 37 \\
\hline & Sec2 & 1 & 3 & 1 & 3 & 0 & 5 & 5 & 0 & 3 & 0 & 2 & 1 & 1 & 1 & 1 & 0 & 27 \\
\hline \multicolumn{2}{|l|}{ Total } & 6 & 5 & 8 & 14 & 1 & 16 & 16 & 4 & 23 & 1 & 16 & 2 & 13 & & & 1 & 134 \\
\hline \multicolumn{2}{|l|}{ Percent } & \multicolumn{4}{|c|}{$24.6 \%$} & & & & & & & & & & & $6.4 \%$ & & \\
\hline
\end{tabular}

\section{Student Expectations \& Perceptions of Learning}

Students had fairly high expectations that they would benefit from digital media learning going into these courses, with $68 \%$ reporting strong or very strong agreement for expectation of a positive learning experience. At the end of the course, $58 \%$ reported that media used in the courses positively affected their learning experience. While viewing media output was voluntary, only a small percentage of students did not view available lecture captures or course podcasts, or did so and did not find them valuable (see Table 6, 1 is low). 
Table 6. Expected \& Actual Positive Learning Outcomes (5=high)

\begin{tabular}{|c|c|c|c|c|c|c|c|}
\hline \multicolumn{4}{|c|}{ Expected Positive Experience } & \multicolumn{4}{|c|}{$\begin{array}{c}\text { Reported Positive Learning Experi- } \\
\text { ence }\end{array}$} \\
\hline & Freq & Percent & & & Freq & Percent & \\
\hline 1 & 1 & 1.0 & & 1 & 2 & 2.1 & \\
\hline 2 & 10 & 10.3 & & 2 & 11 & 11.3 & \\
\hline 3 & 20 & 20.6 & & 3 & 28 & 28.9 & \\
\hline 4 & 43 & 44.3 & \multirow{2}{*}{$68 \%$} & 4 & 45 & 46.4 & \multirow{2}{*}{$58 \%$} \\
\hline 5 & 23 & 23.7 & & 5 & 11 & 11.3 & \\
\hline Total & 97 & 100 & & Total & 97 & 100 & \\
\hline
\end{tabular}

We looked further at the data to review positive expectations and positive learning experiences by learning style. $57.7 \%$ of high visual learners expected to have a positive learning experience and $50.3 \%$ reported they did at the end of the course (see Table 7 ).

Table 7. Expectations and Outcomes by Learning Style

\begin{tabular}{|c|c|c|c|c|c|}
\hline & $\begin{array}{l}\text { High Vis- } \\
\text { ual }\end{array}$ & $\begin{array}{l}\text { High Ver- } \\
\text { bal }\end{array}$ & $\begin{array}{l}\text { High Ac- } \\
\text { tive }\end{array}$ & $\begin{array}{l}\text { High Re- } \\
\text { flective }\end{array}$ & Total \\
\hline $\begin{array}{l}\text { Positive Expectation at } \\
\text { Course Start }\end{array}$ & 56 & 13 & 48 & 37 & \multirow[t]{2}{*}{97} \\
\hline & $57.7 \%$ & $13.4 \%$ & $49.5 \%$ & $38.1 \%$ & \\
\hline \multirow[t]{2}{*}{$\begin{array}{l}\text { Perceived Positive Learning } \\
\text { Experience at Course End }\end{array}$} & 66 & 12 & 62 & 39 & \multirow{2}{*}{131} \\
\hline & $50.3 \%$ & $9.2 \%$ & $47.3 \%$ & $29.7 \%$ & \\
\hline
\end{tabular}

Table 8 summarizes data response for a series of questions on how students perceived the process of using and developing digital media, as well as their preferences for digital lectures over traditional forms. Percentage outcomes were calculated on those reporting 4 or 5 (agree or strongly agree) for this series of questions, with sub-totals by course.

At the end of their courses, $54.2 \%$ of students across all sections felt that using digital media in the form of either lecture capture or podcasts along with creating their own media helped them learn the course materials.

Interestingly, not all students are ready to give up the traditional classroom lecture format. When asked if they preferred watching lecture capture or podcasts over attending a live lecture, $45 \%$ disagreed or strongly disagreed with the statement, and another $30 \%$ were neutral. Only onequarter of the students $(25.2 \%)$ would rather view digital media than attend a lecture.

Supporting the benefits of active learning and the revised Bloom's higher order skills, $56.3 \%$ of students reported that creating media enhanced their learning of the subject matter. 
Table 8. Student Perceptions of Learning with Digital Media

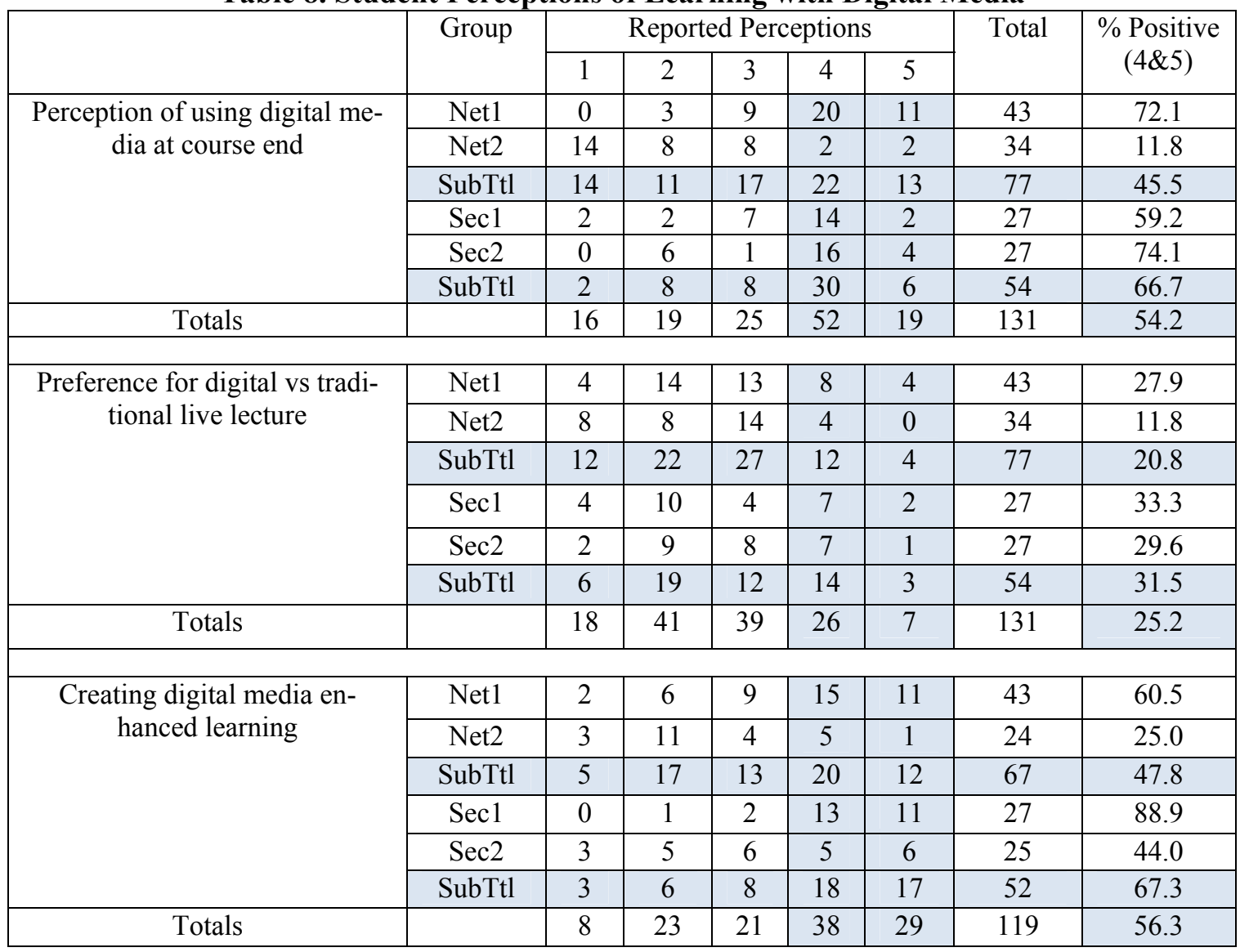

Slightly less than half (46.6\%) of the students felt that having access to the digital media changed the way they prepared for class, and $55.7 \%$ felt it changed the way they studied for exams (see Table 9).

Table 9. Change in Student Study \& Exam Preparation Habits

\begin{tabular}{|l|cccccccc|}
\hline \multicolumn{1}{|c|}{ Dimension } & 1 & 2 & 3 & 4 & 5 & Total & $\%$ \\
\hline Change in Preparation for Class & 7 & 26 & 37 & 47 & 14 & 131 & $46.6 \%$ \\
Change in Preparation for Exams & 4 & 20 & 19 & 42 & 12 & 97 & $55.7 \%$ \\
\hline
\end{tabular}

In spite of the reported effect of having to do more work to create digital media (62\% agreeing or strongly agreeing,), a slight majority (52.9\%) of students would choose this option over giving a live presentation. Slightly less than half $(48.5 \%)$ of our students indicated they would choose the option of creating digital media in the future if the option was available to them (compared to $20.7 \%$ who would not $-30.8 \%$ were ambivalent) (see Table 10 ). 
Table 10. Degree of Effort, Preference of Video over Presentation, Future Intent to Adopt

\begin{tabular}{|lccccccc|}
\hline Dimension & 1 & 2 & 3 & 4 & 5 & Total & $\%$ \\
Video Required Increased Effort & 11 & 14 & 21 & 47 & 28 & 121 & $62.0 \%$ \\
Preferred Video Development Over Presentation & 10 & 17 & 30 & 34 & 30 & 121 & $52.9 \%$ \\
Future Intent to Adopt Media & 5 & 22 & 40 & 38 & 25 & 130 & $48.5 \%$ \\
\hline
\end{tabular}

\section{Discussion}

Observations from our two-year study are summarized here and categorized by the research objectives.

1. Enhance student engagement and learning with course concepts and activities by using digital media produced both by students and faculty.

The process of adding digital content to a course requires careful planning to find or create materials that add value while engaging student interest. Whether simply moving to lecture capture technology or redesigning a course in an inverted format, careful consideration is required to ensure that enough emphasis is placed on key concepts, and in the process finding that perhaps material of lesser importance should be eliminated. In the process of our redesigns, we discovered that some students are more interested in new classroom formats and technologies than others.

Implementation barriers also existed for our project and were primarily related to (1) challenges in integrating new technologies and techniques into class pedagogy and (2) locating and using appropriate technical support. Some challenges were less related to technical limitations than in dealing with the vast new resources made easily accessible through technology. As noted, publicly available media is extensive and requires time to find appropriate content.

2. Evaluate student perceptions, adoption choices, and satisfaction both with studying and creating digital media as part of the learning process.

Most students seemed genuinely interested in trying new forms of content presentation and were willing to learn new tools to create their own media. This application of Bloom's higher order thinking skill of creating content was deemed successful in that more than half (52.9\%) of students preferred developing digital content to writing and presenting a traditional semester report; they reported that they learned both from the process of having to develop content and in working with various tools and media formats. At the same time, most students $(74.8 \%)$ are not willing to move to a digital only format for lectures, and several made additional comments in our surveys about the interaction that is missed while viewing digital lectures. Some students were clearly not interested in creating digital content or felt that it was too time consuming (see Table 11). 
Table 11. Select Student Comments from End of Course Survey

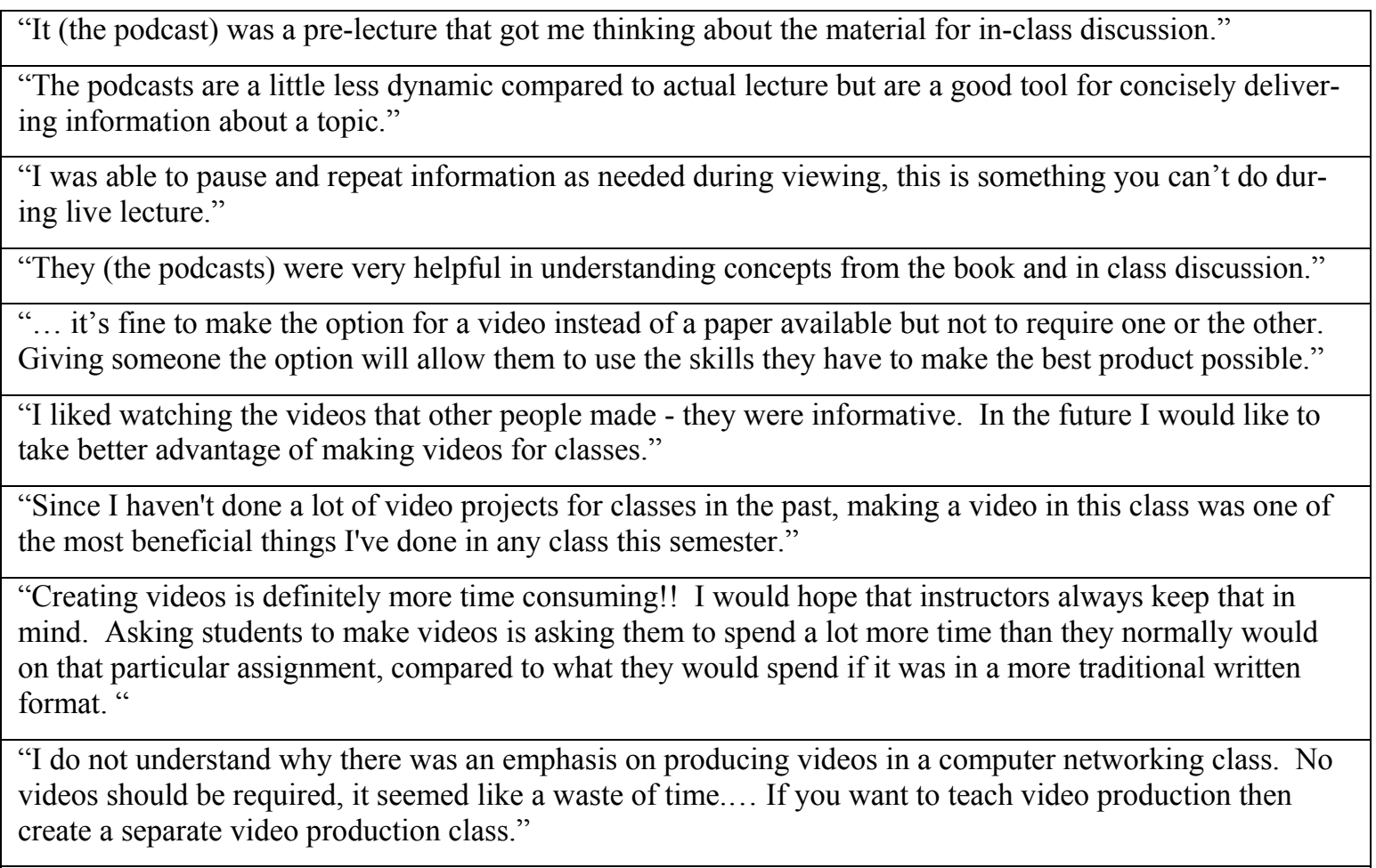

3. Determine whether certain learning styles are related to the above perceptions, adoption choices, and satisfaction measures.

While our sample size was not sufficient to draw strong conclusions about learning styles and learning media preference, our population of IT majors included a high percentage of visual learners $(65 \%)$. Students who are attracted to the IT major eventually realize they have made a life-long commitment to learning. Both the visual experience of seeing how technology works or how code behaves and the active, hands-on approach of quality IT education supports the need for new forms of learning experiences and content forms to prepare them for this continuing process. Some students clearly felt that the skills learned in the process of creating digital media would be useful to them in their IT careers.

4. Develop a set of good practices for future courses and to share with others.

The following recommendations resulted from our experience with using video and other digital media in our courses. These recommendations are general enough to apply to digital media production efforts beyond first time use and are broken into categories of pedagogy, technology and support. They have proven useful to use as we continue to enhance our ITM courses.

\section{Pedagogy}

- Determine how digital media can complement existing course content and support student learning; video may not be appropriate for every course, or every topic

- Avoid asking students to do anything you haven't tried yourself; commit to understanding the technology and the time and effort required

- Develop clear instructions for student-produced video projects, setting expectations about the goals, time commitment, available technology and support 
- Assign at least one project in small groups to allow students to learn from each other and share the time commitment

- Allow sufficient time to review publicly available media for appropriateness and reusability relevant to course content

- Carefully cover the use of intellectual property and web resources \& determine how such content should be cited (i.e., credits page with numbered references throughout)

- Develop grading rubrics to establish expectations for student output and to translate existing project guidelines to digital media output

- Determine campus resources for course development

\section{Technology}

- Start small and early; choose a small number of software tools and spend time upfront learning features and capabilities; determine campus resources for tool and course support

- Choose a limited number of software features and become familiar with them; add more advanced features as experience grows, possibly in second year

- Allow time to produce good quality output, at least double or more time over traditional lecture development, and strive for reusability

- Understand the hardware requirements of the software tools selected, that audio editing may consume considerable system resources, and output will require reliable storage space

- Be aware that everything will take longer than planned

\section{Training \& Support}

- Give students general tutorials on the tools available to them even though they feel they can handle any technology

- Develop reusable tutorials and tips, and seek available campus resources to assist with training and ongoing support

- Work with other faculty to share experiences and successes without having to learn everything alone

\section{Conclusion}

This study advances research into IT education in several ways. First it helps demonstrate the value of applying constructionist learning theory from other disciplines to IT education. Our experience also supports the benefits of using the revised Bloom's Taxonomy framework for active learning with technology in the classroom. Additionally, with this rich framework at hand we are justified in letting students explore and create their own learning objects, therefore enhancing student engagement and achieving the higher level thinking skills that comes with creating their own learning content.

Strategies for increasing the successful adoption of digital media into the curriculum must revolve around support from university technology departments. Without adequate sources and training resources, the time commitment can easily become excessive, discouraging many faculty members from trying new tools and technology. Most schools are supportive of new technology adoption, but technology groups organized by specialty can make it challenging to find the right help on a timely basis. 


\section{Acknowledgement}

This work was funded by an Idaho Technology grant which is invaluable in helping faculty try new things with technology and providing support for pioneering efforts.

\section{References}

Ackerman, E. (n.d.). Piaget's constructivism, Papert's constructionism: What's the Difference? MIT Publications. Retrieved from:

http://learning.media.mit.edu/content/publications/EA.Piaget\%20\%20Papert.pdf

Ahmed, F., Campbell, P., Jaffar, A. Alkobaisi, S., \& Campbell, J. (2010). Learning \& personality types: A case study of a software design course. Journal of Information Technology Education: Innovations in Practice, 9, 237-252. Retrieved from http://www.jite.org/documents/Vol9/JITEv9IIPp237252Ahmed823.pdf

Anderson, L. W., \& Krathwohl, D. R. (Eds.) (2001). A taxonomy for learning, teaching, and assessing: A revision of Bloom's taxonomy of educational objectives. New York: Addison Wesley Longman.

Anderson, L. W., \& Sosniak, L. A. (Eds.) (1994). Bloom's taxonomy: A forty-year retrospective. $93^{\text {rd }}$ Yearbook of the Society for the Study of Education. Chicago, Il: University of Chicago Press.

Bloom, B. S. (Ed.), Engelhart, M. D., Furst, E. J., Hill, W. H., \& Krathwohl, D. R. (1956). Taxonomy of educational objectives: Handbook I: Cognitive domain. New York. David McKay.

Bower, M., Hedberg, J., \& Kuswara, A. (2010). A framework for Web 2.0 learning design, Educational Media International, 47(3), 177-198.

Buckley, J. (2003). Bloom's taxonomy: A framework for assessing programmers' knowledge of software systems. $11^{\text {th }}$ IEEE International Workshop on Program Comprehension, Dublin, Ireland, p. 165-174.

Cegielski, C., Kazen, B., \& Rainer, R. (2011). Teach them how they learn: Learning styles and information systems education. Journal of Information Systems Education, 22(2), 135-146.

Churches, Andrew. (2009). Bloom's digital taxonomy. Retrieved from: http://edorigami.wikispaces.com

Clump, M., \& Skogsberg, K. (2003). Differences in learning styles of college students attending similar universities in different geographic locations. College Student Journal, 37(4), 501-509.

Felder, R. (1996). Matters of style. ASEE Prism, 6(4), 18-23.

Felder, R., \& Brent, R. (2005). Understanding student differences. Journal of Engineering Education, 94(1), 57-72.

Felder, R., \& Silverman, L. K. (1988). Learning and teaching styles in engineering education. Engineering Education, 78(7), 674-681.

Felder, R., \& Soloman, B. (1993). Learning styles and strategies. North Carolina State University. Retrieved 7/2009 from: http://www4.ncsu.edu/unity/lockers/users/f/felder/public/ILSdir/styles.htm

Felder, R., \& Soloman, B. $(1999,2005)$. Index of Learning Styles (ILS). Available at: http://www4.ncsu.edu/unity/lockers/users/f/felder/public/ILSpage.html

Felder, R., \& Spurlin, J. (2005). Applications, reliability and validity of the index of learning styles. Journal of Engineering Education, 21(1), 103-112.

Forehand, M. (2010). Bloom's taxonomy: From emerging perspectives on learning, teaching, and technology. Retrieved from:

http://www.roe11.k12.il.us/GES\%20Stuff/Day\%204/Process/Blooms/Mary\%20Forehand\%20discussio n-Bloom $\% 27 \mathrm{~s} \% 20$ Taxonomy.pdf

Hermann, N. (1990). The creative brain (Hermann Brain Dominance Instrument). N. Carolina, USA: Brain Books. 
Jones, C., Reichard, C., \& Mokhtari, K. (2003). Are students' learning styles discipline specific? Community College Journal of Research and Practice, 27(5), 363-375.

Kolb, D. (1984). Learning Style Inventory (LSI). Experiential learning: Experience as the Source of Learning and Development. Englewood Cliffs, NJ: Prentice-Hall.

Manochehri, N. and Sharif, K. (2010). A model-based investigation of learner attitudes towards recently introduced classroom technology. Journal of Information Technology Education, v9, 31-52.

Mishra, P., \& Koehler, M. J. (2006). Technological, pedagogical, content knowledge: A framework for teacher knowledge. Teachers College Record, 108(6), 1017-1054.

Myers-Briggs, I. McCaulley, M. Quenk, N., \& Hammer, A. (1998). Manual: A guide to the development and use of the Myers-Briggs Type Indicator (3rd ed.). Consulting Psychologist Press.

Papert, S. (1986). Constructionism: A new opportunity for elementary science education. Unpublished proposal to the National Science Foundation (in Bower et al., 2010).

Platsidou, M., \& Metallidou, P. (2009). Validity and reliability issues of two learning style inventories in a Greek sample: Kolb's Learning Style Inventory and Felder \& Soloman's Index of Learning Styles. International Journal of Teaching and Learning in Higher Education, 20(3), 324-335.

Reed, W., \& Oughton, J. (1998). The effects of hypermedia knowledge and learning styles on the construction of group concept maps. Computers in Human Behavior, 14(1), 1-22.

Rosati, P., \& Felder, R. (1995). Engineering student responses to an index of learning styles. Proceedings of the 1995 ASEE Annual Conference, Washington, DC, ASEE.

Salter, D., Evan, N., \& Forney, D. (2006). A longitudinal study of learning style preferences on the MyersBriggs Type Indicator and Learning Style Inventory. Journal of College Student Development, March/April 47(2), 173-184.

Sardone, N. (2011). Developing information technology fluency in college students: An investigation of learning environments and learner characteristics. Journal of Information Technology Education, 10, 101-122. Retrieved from http://www.jite.org/documents/Vol10/JITEv10p101-122Sardone846.pdf

Zualkerman, I. A. (2006). Learning styles of computer programming students: A Middle Eastern and American comparison. IEEE Transactions on Education, 49(4), 443-450. 


\section{Appendix \\ Instruments Used in this Study}

\section{Pre-Course: Technology Experience Survey}

Please answer the following questions about the technology you regularly use:

1. I have a computer at home

2. I have broadband Internet access at home (Quest DSL, CableOne, etc.)

3. If you have a fast Internet connection, what is your download speed in Mbps?

4. I have a laptop or netbook computer

5. I have a mobile device that plays audio files (MP3)

6. If you have a mobile audio device, what kind/model?

7. I have a mobile device that plays video files (MP4)

8. If you have a mobile device that plays video, what kind/model?

9. What make and model of mobile phone do you use?

10. Do you have a $3 \mathrm{G}$ or better data plan with your phone?

11. Do you have an unlimited texting plan with your phone?

12. Does your phone have a web browser?

13. If yes to above, what operating system is on your phone? (Android,

14. Windows Mobile, IOS, Blackberry, etc)

Please indicate your level of experience with the following technologies: $(1=$ none, $5=\mathrm{a}$ lot $)$

15. Watching videos on public Internet sites such as YouTube

16. Listening to audio from public sites such as Internet radio.

17. Subscribing and listening to podcasts from any source

18. Subscribing and listening to podcasts from iTunes

19. Subscribing and listening to podcasts from iTunesU (educational materials)

20. Contributing to a wiki

21. Receiving tweets on Twitter

22. Sending your own tweets on your own Twitter account

23. Maintaining your own Facebook page

24. Maintaining your own LinkedIn presence

25. Maintaining your own blog

26. Maintaining your own web site (other than those mentioned already)

27. Doing your own digital audio recording

28. Using any audio editor such as Audacity

29. Doing your own video recording

30. Using any video editor such as Windows Movie Maker

31. Uploading your videos to YouTube or another public site

32. Doing screen recordings with a tool such as Camtesia that adds audio to PowerPoint, or captures screen content

33. In addition to what was asked about already, do you use any other hardware or software to listen to, watch, create, edit, or publish digital audio or video materials? If so, please list what you use and what you use it for.

34. In addition to what was asked about already, do you use any other social networking tools or sites? If so, please list what you use and what you use it for. 
35. Do you have a job that involves extensive work with or support of computers or information technologies? If so, please explain what you do.

36. Do you have any other experience with computers or IT you'd like to mention?

37. Please enter your name.

38. Please enter your student ID. Thanks for your assistance!

\section{Mid-Term Course Survey}

1. Compared to your other classes, the workload for this class so far is $(1=$ Much lower; $2=$ Somewhat lower; $3=$ About the same; $4=$ Somewhat higher; $5=$ Much higher).

2. How many of the PowerPoint podcasts have you listened to?

3. How many of the Audio only podcasts have you listened to

4. How many of the posted notes pages have you studied?

5. Which media has been your preferred choice for: (a. Preparing for class; b. Studying for exams; c. Clarifying a specific topic)
a. Powerpoint Podcasts
b. Audio Podcasts
c. Posted Notes
d. N/A

Please answer the following questions using this scale: (1. I learn much less; 2 . I learn a little less; 3. I learn about the same; 4. I learn a little more; 5. I learn much more).

6. Compared to conventional in-class lectures, what value do PPT Podcasts have?

7. Compared to conventional in-class lectures, what value do Audio Podcasts have?

8. Compared to conventional in-class lectures, what value do the hands-on labs offer?

9. Compared to conventional in-class lectures, what value do the in-class activities offer?

10. What value did the video assignment have compared to writing a paper?

11. If I were given the choice of semester class project formats: (1) a conventional written project report (typically 10-15 pages, with references); or (2) a video project report (typically 10 to 15 minutes, with a short paper and references); I would: (1.Strongly prefer a conventional written project report; 2 . Slightly prefer a conventional written project report; 3 . Not have a preference either way; 4 . Slightly prefer a video project report; 5 . Strongly prefer a video project report.

12. Any comments on the class format to this point? (use reverse side if needed)

\section{End of Course Media Survey}

A. All questions in this section relate to course podcasts. Please respond using the following scale: (1. Strongly disagree; 2. Disagree; 3. Neutral;. 4. Agree; 5. Strongly Agree)

1. At the beginning of the semester, the idea of using podcasts to learn course materials appealed to me.

2. At the end of the semester, I feel using podcasts did help me learn the course materials.

3. The availability of course podcasts changed my study habits when preparing for class.

4. The availability of course podcasts changed my study habits when studying for exams.

5. The podcast delivery format enhanced my learning experience.

6. Podcast delivery format make learning more enjoyable. 
7. I prefer the flexibility that podcasts provides.

8. I prefer podcasts for course delivery to attending lectures.

9. I did not use the podcasts at all because I learn better from face-to-face classroom experience.

10. I prefer the combination of podcast course delivery with the face-to-face classroom experience.

11. My reading time decreased with the addition of podcasts.

12. My study time increased with the addition of podcasts.

13. I viewed podcast course materials for the following reasons (choose all that apply):

a. Required content in other formats

b. Missed lectures

c. Making up notes from class

d. Course content preview

e. Course content review

f. Convenient access

g. Flexibility

h. Portability

i. Ease of use

j. I did not view any podcasts

14. Which of the following features of podcasts did you find most valuable?

a. I could review materials wherever I wanted

b. I could review materials whenever I wanted

c. I could review materials at my own pace

d. I felt the materials were covered more clearly

e. I learned the material better

f. I felt more involved with the material

g. I did not find podcasts valuable

15. Do you have any other comments about our use of podcasts this semester?

B. All questions in this section relate to video projects. Please respond with the following scale: (1. Strongly disagree; 2. Disagree; 3. Neutral; 4. Agree; 5. Strongly Agree.)

1. At the beginning of the semester, I already had prior experience creating my own videos.

2. At the end of the semester, I now feel confident that I can create my own videos.

3. I find it easy to create videos.

4. There is adequate hardware and software available for me to create videos.

5. There is adequate technical assistance to help me create videos.

6. I feel the video I created for my project is more effective in communicating the results of my work than a paper would have been.

7. Creating a video for my project enhanced my learning experience.

8. Creating a video for my project made learning more enjoyable.

9. I prefer delivering my project results in the form of a pre-recorded video rather than a live presentation.

10. I spent more effort creating video than I would have with a conventional paper project report.

11. My effectiveness as a student/learner would be improved if video were more integrated into the curriculum.

12. I think it would be a good idea for instructors to offer the video format as an option to paper project reports. 
13. I think it would be a good idea for instructors to require the use of video instead of paper project reports.

14. The experience and skills I gained creating videos will help me in my career.

15. If future classes offer the option of creating videos for projects, I will take that option.

16. Preparing a video topic helped me understand the topic better than traditional course materials.

17. Watching a video presented by students helped me understand the topics better than traditional course materials.

C. Do you have any other comments about our use of videos for projects this semester?

\section{Biographies}

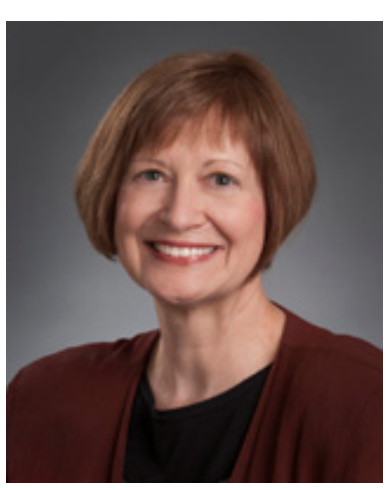

Sharon W. Tabor is Professor of Information Technology Management at Boise State University, College of Business and Economics. She received her Ph.D. from the University of North Texas following a lengthy management career. Dr. Tabor's current teaching and research interests include information security, business intelligence, IT service management, and mobile learning. She has published in various journals including Communications of the ACM, Decision Science Journal of Innovative Education, Journal of Information Technology Education, Journal of Information Technology Cases and Applications, and the Quarterly Review of Distance Education.

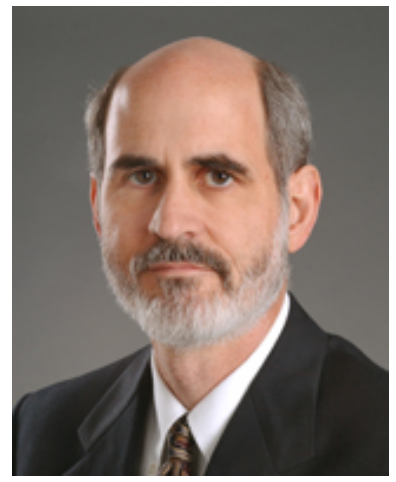

Dr. Robert Minch is Professor of Information Technology Management in the College of Business and Economics at Boise State University. His PhD in Management Information Systems was earned at Texas Tech University in 1982. Dr. Minch has published several dozen research articles in academic journals and the proceedings of national and international conferences, including MISQ, JMIS, CACM, ICIS, and HICSS. He currently teaches classes in computer networking, and conducts research on topics such as privacy implications of location-aware mobile computing devices. 